\title{
THE STATUS OF AN ATTORNEY DEFENDING A GUILTY CLIENT.
}

Mr. William Navis was unquestionably right when he said: "It is one of the worst of errors to suppose that there is any path of safety except that of duty." But what is our duty is not always easy to determine. The complexity of the situation in which we are sometimes placed, makes it often difficult to decide. It happens thus, that the status of the attorney to his guilty client, is not infrequently a matter causing him much perplexity.

Abraham Lincoln once replied to a client, after he had stated his case to him, in the following language: "I can't serve you, for you are wrong and the other fellow right. My business is never to defend wrong. I never take a case that is manifestly wrong." It is also reported of Sir Matthew Hale, that in his early practice he made it his rule not to defend a client that appeared to him to be guilty. This is the position still taken by a number of prominent attorneys to-day.

But a somewhat careful examination of this subject will clearly show that this is far from being the best attitude to take. In fact, Sir Matthew Hale himself repudiated that position in the later years of his practice. He realized, that refusing to defend a client, simply because appearances seemed to indicate that he was guilty, would be acting as judge of the case, not as attorney.

It is an elementary principle of American Civics, that every man has a right to be defended, no matter how guilty he may be. The sixth amendment of the Federal Constitution expressly states: "In all criminal prosecutions, the accused shall enjoy the right to a speedy and public trial, and, to have the assistance of counsel for his defense." Most of the State constitutions contain provisions to the same effect. The right of having assistance of counsel includes also the right of consultation; and also the right to have the attorney's advice and instructions on all matters pertaining to the prisoner's defense. (See People . Risely $13 \mathrm{Abb}$. N. C., (N. Y.) 186). Even in cases 
where the accused is a lawyer himself, this right is enforced, and the prisoner must be granted the privilege of securing efficient assistance of counsel. (People v. Naphtaly, 105 Cal. 641; 39 Pac. 29.) In truth, so desirous is the law to enforce this constitutional right, that in cases where the accised has not the means to engage counsel, the court will appoint one for him, and the attorney so appointed will not be permitted to refuse. (See Kelley ₹. Andreu Co., 43. Mo., 338; Vise ₹. Hamilton Co., 19 Ill., 18.)

Another well-established principle of law is, that every man is presumed to be innocent until the contrary is proved. "This presumption of innocence is so strong that even where the guilt can be established only by proving a negative, that negative must in most cases be proved by the party alleging the guilt; though the general rule of law devolves the burden of proof on the party holding the affirmative. Thus, where the plaintiff complains that the defendants, who had chartered the ship, had put on board an article highly inflammable and dangerous, without giving notice of its danger to the master or others in charge of the ship, whereby the vessel was burned, he was held bound to prove this negative averment." Greenleaf on Evidence, Vol. 1, p. 130, 16th edition. (Powell v. Milburn, 3 Wils. 355, 366; Rodwell v. Redge, 1 C. \& P. 220.)

It is obvious then, from the above, that to refuse to take up a cause, simply because the client appears to be guilty, would be to pass "judgment on him and sentence him to a deprivation of the legal services of his (the client's) chosen counsel, in violation of his constitutional right to be regarded as innocent until he has been proven guilty." With all due respect, therefore, to our immortal President, we do not think his attitude a proper one to be followed by the legal profession.

It might be remarked, however, that an attorney not engaged in the actual practice of criminal law may sometimes properly decline to take up a criminal case; but generally speaking, no lawyer, certainly no criminal lawyer, should decline taking up a cause simply because a client appears to be guilty. Section 13, Code of Ethics of the Alabama Bar Association provides, that "An attorney cannot reject the defense of a person accused of a criminal offence, because he knows or believes him to be guilty."

Taking up a defence, however, should never imply recourse to what is known among the members of the Bar as "sharp practice." A lawyer is-though in a limited sense-an officer of 
the court. Hence it is his duty to help the administration of law, not to hinder it. To defeat the ends of justice, is the work of the pettifogger, not of the lawyer. Truly say Frank S. Deneen, District Attorney at Chicago, Edwin M. Ashcraft, and F. A. Johnson, in the disbarment case of in re-Pickler, at the conclusion of their brief: "He (meaning the lawyer) was the friend, assistant, and officer of the court, before he was the attorney of this client, and that, as such officer, it is his first sworn duty to honestly and earnestly labor to render aid to the court, to arrive at the correct conclusion upon the facts of the law." It follows therefore, as a logical corollary from the above, that under no circumstances has a lawyer the right to herald honest people as perjurers, make use of equivocal terminology, intimidate witnesses, manufacture alibis, or tell lies, simply because, by doing so, he would advance the interests of his client.

It is certainly true that a lawyer is only bound to present one side of the case. But in doing that, he must not use unfair or unlawful means. Once retained, he is bound to exert all his industry in defending his client, no matter how guilty he may be; but the arguments used must be truthful and in accordance with the evidence in the case. As long as he does not go outside of the evidence, he may give his client the benefit of all fair advantages. In fact, we would say that he should do so, because a lawyer should always exercise the best of his ability. Our courts recognize this, and have therefore held that our Constitution, by implication, guarantees to the counsel of the accused independence in his entire management of the case, and in his examination of witnesses and his comments and arguments. (See Cooley's Constitutional Limitations, 443, and the cases cited by him.) In order also that the attorney should be able to fully serve his client, our Supreme Court, in the case of Central Trust Company v. Milwaukee Street Railway Company, 74. Fed. 442, has held, that a lawyer is not subject to service of process while attending court in the interest of a client. For the same reason, too, most of the states have made enactments exempting attorneys from service as jurors.

In applying himself to the protection and defence of his client, he may also do things for him which he would not do for himself. Thus, to enforce certain obligations or to avail himself of certain advantages, may sometimes be a little contrary to his own feelings, but if the law requires it and his client insists on it, he must do his duty as a lawyer. Were it 
his own case he might make some concessions or waive certain advantages, but in his client's case he has no right to make any such concessions or abjure any such advantages. And although it may be from truly moral principles that he is disposed to give those rights away, he dare not do so, because they are not his. He is the custodian of his client's rights, the guardian of his interests. Furthermore, his duty is not only to exercise integrity, care and diligence, but also skill. In fact, so much latitude is given to the attorney, in the exercise of his tact, that if necessary to his defence, he may use defamatory words about parties on the other side; provided, of course, there is proper cause. His conduct is certainly always subject to the ordinary rules of propriety. An attorney will never be allowed to abuse the character of a private person wantonly or maliciously. (See Munster v. Lamb, 11 Q. B. Div., 588; Wood v. Gunston, Styles 462.) Words expressive of hard and bitter feelings are also sometimes unbecoming to the dignity of the court; hence cases may frequently arise where the use of defamatory words will be repressed. But where there are good grounds and it is necessary to a client's defence, defama. tory words may justly be used. (See Mower v. Watson, 11 Vt. 356; Bradley v. Heath, 12 Pick. 163; Garr v. Selden, 4 N. Y. 91.

To recapitulate then, it may be stated that as a general proposition no lawyer has a right to decline a case simply because the party seems to be guilty. No one can form an opinion until he has heard all the facts of the case. Furthermore, judging is not the function of the lawyer. The lawyer's duty is to present his side of the case to the best of his ability. On the other hand, no lawryer should ever tarnish his honor for any client. Under no consideration should he ever resort to any unlawful means. His conscience should never be for sale. The lawyer should be the best type of man; and honesty and honor should ever be his guide.

LouIS J. ROSENBERG. 